\title{
CARDIOTOXICITY DUE TO OCCUPATIONAL EXPOSURE TO FREON
}

\author{
By \\ Soliman E. F. \\ The National Egyptian Center of Env. \& Toxicol. Research, \\ NECTR, Faculty of Medicine, Cairo University.
}

\begin{abstract}
:
Objective: The present study was designed to investigate cardiovascular manifestations among occupationally exposed workers to Freon and to assess environmental exposure during the maintenance step of air-conditioners.
\end{abstract}

Subjects and Methods: This study was conducted on twenty four workers occupationally exposed to the Freon 11 with the duration of exposure ranged from 7 to 14 years for 30 to 60 minutes/day and control group $(\mathrm{No}=20)$ working in the same company in the administrative department, were involved in this study. All subjects were personally interviewed and clinically examined. Clinical examination \& full detailed occupational history, such as work hours, type of fluorocarbon exposure and availability of suitable protective equipment were fulfilled. The cardiovascular system was evaluated by measuring blood pressure, heart rate, and resting ECG. Air samples from the breathing zone of the studied refrigeration services workers were collected during the recharging of different devices \& analyzed.

Results: The study revealed that there was statistically significant increase in diastolic blood pressure and heart rate in Freon exposed group than in control. Chest pain and palpitation were observed more significantly among Freon exposed workers when compared to control group ( $\mathrm{p}=<0.05)$. The only ECG findings which revealed statistically significance was the presence of inverted t-waves among Freon exposed workers compared to control. The measured average concentration of Freon in the breathing zone during recharching and repairing activities were found $36,000 \mathrm{mg} / \mathrm{m}^{3}$ that exceed the corresponding normal permissible level $\left(5,600 \mathrm{mg} / \mathrm{m}^{3}\right)$.

Conclusion: Unprotected occupational exposure to chlorofluorocarbons can induce cardio-toxicity in the form of cardiac arrhythmias, or changes in the ECG. These 
changes can be prevented by pre-employment selection of unsusceptible workers and periodic monitoring of cardiovascular parameters indicative of toxicity as doing regular ECG.

Key words: Freon, cardiotoxicity, myocardial ischemia, arrhythmias \& chlorofluorocarbons.

\section{Introduction}

Fluorocarbons are a group of synthetic halogen-substituted methane and ethane derivatives containing atoms of chlorine and fluorine and are commonly known as chlorofluorocarbons (CFCs). They are generally known by commercial names such as freon, arcton and frigen (Blanda $\mathrm{M}$ \& Weigand J 1998).

Chlorofluorocarbons (CFCs), are stable, nonflammable, noncorrosive, low in toxicity and inexpensive to produce ( Payne M \& Rubenstein R, 2001). CFCs are very useful compounds that had been used for years as coolants and as spray propellants for aerosol forms of hair sprays and deodorants. They had been unsurpassed as solvents for cleaning electronic microcircuits. Commercially, the most important CFCs are the halogenated methanes, Freon-11 (trichlorofluoromethane) and Freon-12 (dichlorodifluoromethane).

In 1974, scientists discovered that CFCs have the capability of depleting the stratospheric ozone layer. Since the 1990s, according to the Montreal Protocol on
Substances that Deplete the Ozone Layer, developed countries have replaced CFCs and hydrochlorofluorocarbons (HCFCs) (hydrogenated chlorofluorocarbons) with hydroflurocarbons (HFCs) which is chlorine free hydrogenated fluorocarbons (Molina MJ, 2007 ).

Although Freon is generally considered to be a fluorocarbon of relatively low toxicity; significant toxic effects may occur when significant over-exposure occurs. For example, overexposure to CFCs and related halogenated hydrocarbons can cause arterial hypertension, myocardial infarction and temporary alteration of the electrical activity of the heart (atrial and ventricular cardiac arrhythmias) manifested with palpitations, irregular pulse or even inadequate circulation. Cardiac arrest and death may occur from gross overexposure (Brock WJ, 2007).

There are isolated reports of poisoning from exposure to Freon showing a higher incidence of coronary heart disease among hospital personnel required to establish causal relationship between fluorine containing organic compounds, and 
cardiovascular diseases among exposed workers (Clayton and Clayton, 1994).

\section{Aim of the work}

The primary focus of this work is to assess environmental exposure to Freon during the maintenance step of air-conditioners. Also we aimed at demonstrating the association between cardiovascular manifestations and the hazard of Freon exposure in selected exposed workers.

\section{Subjects and Methodology}

This comparative cross-sectional study was carried out at one of largest companies in Egypt for production of air conditioners. The whole working population involved in the stage of maintenance of the air conditioner units were recruited (No =24). They were working on a 12 hours based shift. A matched control group (No =20) working in the same company in the administrative department, were also involved in our study.

All subjects were personally interviewed and clinically examined. Detailed occupational history, such as work hours, type of fluorocarbon exposure and availability of suitable protective equipment was fulfilled. The cardiovascular system was evaluated by measuring blood pressure, heart rate, and resting ECG.
Our studied groups were matched concerning age, sex, smoking habit, marital and socioeconomic status. They have no family history of dyslipidemia or hypertension and coronary artery disease. However, none of the workers in the study had a past medical history of arrhythmias, coronary artery disease and arterial hypertension.

We relied on NIOSH standardized sampling and analytical methods, to assess the workplace environment, for the exposure to Freon 11. A total of five air samples from the breathing zone of the studied refrigeration services workers were collected during the recharging of different devices. Personal sampling was conducted for Freon 11using two charcoal tubes in a series as first tube 400/200 mg, second tube 100/50 mg sections and both 20/40 mesh, which were manufactured by SigmaAldrich/Supelco. At the end of work shift, charcoal adsorption tubes were washed with isopropyl alcohol and the wash was then injected into gas chromatography/ mass spectrometer (GC/MS) for analysis Then the average of the five readings for freon 11 was calculated and compared to the threshold limit values of the American Conference of Governmental Industrial Hygienists (ACGIH)

(TLV-TWA) (threshold limit value - time-weighted average). 


\section{Statistical analysis}

Data were presented as means + S.D and analyzed using kruskal-wallis test, that was determined using a computer software pakage epi-info 1992. A P-value less than 0.05 was considered statistically significant.

\section{Results and discussion}

Table (1) demonstrates no significant statistical difference between the two studied groups as regard age, smoking habits \& marital state $(\mathrm{p}>0.05)$.

Table (2) illustrates that there were significant statistical differences between the exposed workers and control groups as regard symptoms of headache, chest pain and palpitations $(\mathrm{p}<0.05)$.

This study reported, five exposed workers $(20.8 \%)$ were complaining from chest pain, 7 workers $(29.2 \%)$ complained from headache and 3 workers (12.5\%) from palpitation. These symptoms may attributed to inhalation of high concentrations of Freon during repair, which may result in temporary impair the heart oxygenation and alter the electrical nerve impulse activity of the heart to the arrhythmogenic action of epinephrine, causing irregular pulse and palpitations (Reprotext, 2003 \& Tasai, 2005).

Table (3) illustrates that there was no significant statistical differences between the two studied groups as regard systolic blood pressure and respiratory rate $(\mathrm{p}>$ 0.05); while the exposed group showed significantly higher diastolic blood pressure and heart rate than control $(\mathrm{p}<0.05)$.

However, the measure diastolic blood pressure and heart rate among Freon exposed workers were found in the normal range. This may be due to the small sample size or these workers were in the prehypertension state. This could suggest that Freon-exposed workers under normal working conditions are not at an increased risk for arterial hypertension.

Table (4) shows that $\mathrm{T}$ wave inversion is statistically significant among the exposed group when compared to control group $(\mathrm{P}<0.05)$. There was no statistically difference between the two groups $(\mathrm{p}>$ $0.05)$ as regard other parameters.

Ellenhorn, and Barceloux (1988) concluded that Freon 11, inhaled at 5\% concentration, sensitizes the myocardium to epinephrine. $10 \%$ concentration produces cardiac arrhythmias. Deaths resulting from cardiovascular collapse after arrhythmias have been reported after inhalation of Freon 11.

High inhalation of Freon vapors may cause temporary alteration of the heart's electrical activity with irregular pulse, 
palpitations, or inadequate circulation (Kubota and Miyata , 2005). Clinical pathologists exposed to fluorocarbons in the preparation of frozen tissue sections have been seen to develop coronary heart disease (Clayton and Clayton, 1994).

Variations in heart rate \& inversion of T-wave findings in the current study among the exposed workers to Freon are similar to other findings in other study (Valic F. et al., 1977).

Individuals with pre-existing diseases of the cardiovascular system may have increased susceptibility to the effects of Freons (OSHA, 1998). Persons exposed to increased epinephrine as stressful conditions or drinking excessive caffeine or taking other sympathomimetic amines, e.g., bronchodilators and nasal decongestants (e.g., Sudafed), might be at increased risk for the cardiotoxic effects of Freons (Reprotext, 2003).

In the present study, 5 exposed workers had symptoms as chest pain and inversion of $\mathrm{T}$ waves in ECG suggesting the correlation between high level of exposure to Freon and cardiovascular toxicity. Although other finding in other study found that there were no significant statistical differences between exposed and the control group as regards symptoms suggesting arterial hypertension and coronary artery disease (Sabik et al., 2009). This study could suggest that workers exposed to high level of Freon under normal working conditions are at an increased risk for coronary artery disease.

This difference in the results between the present study and the other studies could be due to exposure of workers to different freon levels and to different types inhaled as well as to individual susceptibility (IPCS, 2002).

The Acceptable Exposure Limit (AEL) set by the HCFC-123 manufacturers is 30 $\mathrm{ppm}$. This represents the concentration to which a worker could be exposed 8 hours/ day for a working lifetime without effects. In other words, the AEL is a chronic exposure limit. EPA conducted a study to determine the typical exposure level found in actual equipment rooms. The permissible exposure limit (PEL) according to OSHA is set to be $1,000 \mathrm{ppm}, 5,600 \mathrm{mg} / \mathrm{m} 3,8 \mathrm{Hr}$. TWA, TLV (ACGIH): Ceiling 1,000 ppm, $5,620 \mathrm{mg} / \mathrm{m}^{3}$ (Salocks and Kaley, 2003).

The measured average airborne concentrations of freon at the refrigeration workshop during recharging and repairing activities, were found to be $36,000 \mathrm{mg} / \mathrm{m} 3$, that exceed the corresponding ACGIH TLV (TWA). 
Table (1) General characteristics of the studied groups:

\begin{tabular}{|c|c|c|c|c|c|c|}
\hline & \multicolumn{2}{|c|}{$\begin{array}{c}\text { Exposed group } \\
(\mathrm{n}=24)\end{array}$} & \multicolumn{2}{|c|}{$\begin{array}{c}\text { Control group } \\
(\mathrm{n}=20)\end{array}$} & $\begin{array}{c}\text { Test of } \\
\text { Significance }\end{array}$ & $\begin{array}{c}\mathrm{P} \\
\text { value }\end{array}$ \\
\hline Age $($ mean \pm SD $)$ & \multicolumn{2}{|c|}{$29.10 \pm 7.27$} & \multicolumn{2}{|c|}{$30.20 \pm 5.73$} & 1.04 & $>0.05$ \\
\hline Smoking & 21 & 87.5 & 16 & 80 & 0.15 & $>0.05$ \\
\hline Marital status (married) & 20 & 83.3 & 18 & 90 & 0.41 & $>0.05$ \\
\hline
\end{tabular}

Table (2) Prevalence of cardiovascular manifestations among the studied groups:

\begin{tabular}{|l|cc|cc|c|c|}
\hline & \multicolumn{2}{|c|}{ Exposed group $(\mathrm{n}=24)$} & \multicolumn{2}{|c|}{ Control group $(\mathrm{n}=20)$} & \multirow{2}{*}{$\mathrm{X}^{2}$ test } & \multirow{2}{*}{ P value } \\
\hline No. & \multicolumn{2}{|c|}{ No. $\%$} & \multicolumn{2}{|c|}{ No } & & \\
\hline Headache & 7 & 29.2 & 1 & 0.0 & 3.76 & $<0.01^{* *}$ \\
\hline Chest pain & 5 & 20.8 & 0 & 0.0 & 2.79 & $<0.05^{*}$ \\
\hline Palpitation & 3 & 12.5 & 1 & 8.0 & 2.56 & $<0.05^{*}$ \\
\hline
\end{tabular}

** Highly significant

*Significant 
Table (3) Vital data of the studied groups

\begin{tabular}{|l|c|c|c|c|}
\hline & $\begin{array}{c}\text { Exposed group } \\
\text { Mean } \pm \text { SD }\end{array}$ & $\begin{array}{c}\text { Control group } \\
\text { Mean } \pm \text { SD }\end{array}$ & t test & P value \\
\hline Systolic bl.p $(\mathrm{mmHg})$ & $125.40 \pm 11.50$ & $125.00 \pm 6.30$ & 0.22 & $>0.05$ \\
\hline Diastolic bl.p(mmHg) & $81.80 \pm 9.70$ & $74.01 \pm 6.30$ & 3.52 & $<0.05^{*}$ \\
\hline Heart rate (beats/min) & $76.38 \pm 3.95$ & $62.8 \pm 9.06$ & 3.78 & $<0.05^{*}$ \\
\hline Respiratory rate & $16.30 \pm 1.50$ & $16.60 \pm 0.80$ & -0.83 & $>0.05$ \\
\hline
\end{tabular}

* Significant

Table (4) Resting ECG findings in the two studied groups:

\begin{tabular}{|l|rr|rr|c|}
\hline & \multicolumn{2}{|c|}{$\begin{array}{c}\text { Exposed group } \\
\text { No. (24) }\end{array}$} & \multicolumn{2}{c|}{$\begin{array}{c}\text { Control group } \\
\text { No. (20) }\end{array}$} & P value \\
\hline Bradycardia & 3 & 12.5 & 0 & 0 & $>0.05$ \\
Arrhythmia & 3 & 12.5 & 0 & 0 & $>0.05$ \\
Inversion of the T-waves & 4 & 16.7 & 0 & 0 & $<0.05^{*}$ \\
Atrioventricular block & 1 & 4.2 & 0 & 0 & $>0.05$ \\
\hline
\end{tabular}

* Significant 


\section{Conclusion}

This study indicates that unprotected occupational exposure to freon in the present workplace can induce cardiotoxicity, mainly in the form of cardiac arrhythmias, changes in ECG suggesting coronary insufficiency. Finally, environmental assessment results for freon in the refrigeration services workshop were found to exceed the threshold limit value.

\section{Recommendations}

As Freon exposure is a risk factor for the development of cardiovascular diseases, therefore, it is recommended:

Pre-employment examinations should exclude those individuals with the predisposing conditions to cardiovascular diseases as those with hypertension, hyperlipidemia $\&$ heavy smokers .....ect.

Improved working conditions of all workers exposed to freon, are strongly recommended.

Avoid using or over exposure of workers to any condition that may increase endogenous epinephrine secretion as anger and stress or other sympathomimetic amines, e.g., bronchodilators and nasal decongestants, might be at increased risk for the cardiotoxic effects of Freons during working hours.
Resting ECG should be monitored periodically for all exposed workers.

Health education \& smoking cessation should be emphasized.

Further studies are needed to investigate more details about cardiotoxicity to Freon.

\section{Acknowledgements}

I wish to express my deep gratitude to all examined group of this work for their co-operation \& grateful help.

\section{References}

1. Blanda M, Weigand J. (1989). Freon and Other Inhalants. In Clinical Management of Poisoning and Drug Overdose. 3rd edition. Edited by: Haddad, Shannon M, Winchester J. Saunders Company; 949-955.

2. Brock WJ, Rusch GM, Trochimowicz HJ. (2003). Cardiac Sensitization: Methodology and Interpretation in Risk Assessment. Regul Toxicol Pharmacol, 38:78-90.

3. Clayton, G.D., F.E. Clayton (eds.).(1993-1994). Patty's Industrial Hygiene and Toxicology. Vol 2A, 2B, 2C, 2D, 2E, 2F: Toxicology. 4th ed. New York, NY: John Wiley \& Sons Inc., pp.1209.

4. Dupont: (1996).Material Safety Data Sheet for "Freon" 11. Wilmington, DE.

5. Ellenhorn, M.J. and D.G. Barceloux. (1988): Medical Toxicology - Diagnosis and Treatment of Human Poisoning. New York, NY: Elsevier Science Publishing Co., Inc. pp. 528.

6. F Valić, Z Skurić, Z Bantić, M Rudar, and M Hećej. (1977). Effects of fluorocarbon propellants on respiratory flow and ECG. Br J Ind Med. May; 34(2): 130-136. 
7. Hazardtext. (2003). Hazardtext Hazard Management . Trichloromonofluoromethane. In: Hurlburt, KM (Ed.)

8. International Program on Chemical Safety (IPCS). (2002).

9. Kubota T, Miyata A: (2005).Acute Inhalational Exposure to Chlorodifluoromethane (Freon-22): A Report of 43 Cases. Clin Toxicol (Phila), 43(4):305-308.

10. Sabik LM, Abbas RA, Ismail MM and El-Refaei S. (2009). Cardiotoxicity of Freon among refrigeration services workers: comparative cross-sectional study. Environmental Health. 8:31, 1186/1476-069-8-31

11. Molina MJ and Molina LT. (2007). Chlorofluorocarbons and Destruction of the Ozone Layer. In Environmental and Occupational Medicine. 4th edition. Edited by: Rom WN, Markowitz SB. Lippincott Williams \& Wilkins Press.1605-1615.

12. NIOSH.(2001).National Institute for Occupational Safety and Health, U.S. Department of Health and Human Services. NIOSH Pocket Guide to Chemical Hazards. International Chemical Safety Card for Trichlorofluoromethane. DHHS (NIOSH) Publication No. 145. Publications; Cincinnati, $\mathrm{OH}$.
13. NIOSH, 2003C: (2003). National Institute for Occupational Safety and Health. NIOSH Pocket Guide to Chemical Hazards. 1,1,2-Trichloro1,2,2-Trifluoroethane. In: Hurlburt, KM (Ed.):

14. OSHA. (1998). Occupational Safety and Health Administration. Sampling and Analytical Method for 1,1-Dichloro-1-fluoroethane (Freon 141b) 1,1,2-Trichloro-1,2,2-Trifluoroethane (Freon 113).

15. Payne M and Rubenstein R: (2001) Ozone Depletion and Chlorofluorocarbons. In Environmental Health Secrets. Edited by: Williams LK, Langley RL. Hanley \& Belfus; 25-29.

16. Reprotext. (2003). 1,1-Dichloro-1-Fluoroethane. In: Hurlburt, KM (Ed.). Available at: http:// www.fluoridealert.org/pesticides/Trichlorofluorometha.TOXNET.htm

17. Salocks C, Kaley B. (2003). Freon. Cal/EPA: Office of Environmental Health Hazard Assessment (OEHHA). Available at: http://www.OEHHA.Ca.Gov.

18. Tsai WT. (2005).An Overview of Environmental Hazards and Exposure Risk of Hydrofluorocarbons (HFCs). Chemosphere. 61(11):1539154.

19. WHO. (1990): Environmental Health Criteria 113: Fully Halogenated Chlorofluorocarbons 